\title{
Yazın ve İhanet: Hans Joachim Schädlich'in Die Sache mit B. Yapıtında İhanet İzleğinin Aile Belleği Bağlamında İncelenmesi ${ }^{1}$
}

\section{Yildız AYDIN2}

APA: Aydın, Y. (2018). Yazın ve İhanet: Hans Joachim Schädlich'in Die Sache mit B. Yapıtında İhanet İzleğinin Aile Belleği Bağlamında İncelenmesi. RumeliDE Dil ve Edebiyat Araşttrmaları Dergisi, (12),

323-338. DOI: $10.29000 /$ rumelide.472786

\section{$\ddot{O}_{z}$}

1989 ve 1992 yılları Almanya tarihi bakımından en önemli dönüm noktalarından biri olarak kabul edilmektedir. 1989 yılında bir yandan Berlin Duvarı’nın yıkılmasıyla Doğu ile Batı arasındaki sınır ortadan kalkar, diğer yandan 1990 yılında yaklaşık kırk yıl varlığını sürdüren Demokratik Almanya Cumhuriyeti Federal Almanya’ya katılarak resmen yıkılır. Ne var ki bu hızlı dönüşüm siyasal, ekinsel ve toplumsal açıdan oldukça sancılı gerçekleşmiştir. Sözgelimi Alman toplumunun belleğine yer eden önemli olaylar arasında Milli İstihbarat Teşkilatı'nın Doğu Almanyalı yurttaşlar tarafindan yağmalanması ve arşivlerde bulunan dosyaların bir kısmının tahrip edilmesi sayılabilir. 1992 yılında bu kurumun arşivlerinin kamuoyuna açık tutulması ise tartışmaları yeniden alevlendirmiştir, çünkü bazı dosyalar gizlice basın yayına sızdırılmış ve kimi önemli sanatçıların ve yazarların casusluk yaptığı ortaya çıkmıştır. 1977 yılında DAC'deki baskılara fazla dayanamayarak Federal Almanya’ya göç eden yazar Hans Joachim Schädlich ilk defa o tarihte ağabeyinin bu kuruma kendisi hakkında bilgiler verdiğini öğrenir ve büyük düş kırıklığı yaşar. Birkaç ay sonrasında yayımladığı Die Sache mit B. adlı kısa öyküsünde yüzleştiği bu ihanetle hesaplaşan yazar, geri sapım tekniği ile çocukluğundan bu yazıyı kaleme aldığı ana kadar ağabeyinin aile içindeki rolünü ve ağabey kardeş ilişkilerini çarpıcı bir dille aktarır. Son derece yoğun bir biçimde özyaşamöyküsel öğelere göndergeler taşıyan bu öyküde gerçeklere ulaşma istenci içinde bocalayan anlatıcı, belleğindeki aile anılarını aktararak bu ihaneti sorgulamaktadır. Ağabeyi Karlheinz Schädlich ise bu utançla daha fazla yaşayamayacağını anladığından olsa gerek 2007 yılında intihar eder. Bu çalışmada tarihsel, ekin siyasal ve özyaşamsal kaynaklardan hareketle yazarın ihanet izleğine nasıl yaklaştı̆̆ı sorgulanacak, sonrasında ise Die Sache mit $B$. öyküsü M. Halbwachs'ın aile belleği kuramı çerçevesinde ele alınacaktır ve bu tür aile anılarının yansıtıldığı özyaşamsal veya yaşamöyküsel öğelerin aktarıldığı yazınsal metinlerin yorumlanması veya daha iyi anlaşılmasında ne tür katkı sağlayacağı ortaya konacaktır.

Anahtar kelimeler: Demokratik Almanya Cumhuriyeti, özyaşam, Hans Joachim Schädlich, ihanet, aile belleği.

\section{Literature and Betrayal: Examining Betrayal Theme in Hans Joachim Schädlich's Work Called Die Sache mit B. within the context of Family Memory}

\begin{abstract}
Bu çalıșma 4-6 Ekim 2017 tarihlerinde Sivas'ta gerçekleștirilen V. Uluslararası Batı Kültürü ve Edebiyatları Araştırmaları Sempozyumu'nda (BAKEA) "Bir İhanetin Yazınsal Muhakemesi: Hans Joachim Schädlich'in Yapıtı Die Sache mit B. Üzerine" başlıklı sözlü bildiri olarak sunulmuştur. Ancak hem başlıkta hem de içerikte yapılan önemli değisikliklerle genişletilerek makale haline getirilmiștir.

2 Dr. Öğr. Üyesi, Tekirdağ Namık Kemal Üniversitesi, Fen Edebiyat Fakültesi, Alman Dili ve Edebiyatı Bölümü, yaydin@nku.edu.tr, ORCID ID: 0ooo-0001-8665-7131 [Makale kayıt tarihi: 30.9.2018-kabul tarihi: 19.10.2018]
\end{abstract}

Adres 
Literature and Betrayal: Examining Betrayal Theme in Hans Joachim Schädlich's Work Called Die Sache mit B. within The Context of Family Memory / Y. Aydın (p. 323-338)

Years of 1989 and 1992 are accepted as one of the most important milestones in terms of Germany history. On the one hand, the border between the East and the West disappears with the fall of Berlin Wall in 1989. On the other hand, the German Democratic Republic which continued its existence for almost forty years was officially subverted when it joined to the Federal Republic of Germany in 1990. However, this transformation actualized painfully in terms of political, cultural and social aspects. Among the issues that jogged German people's memory, the plunder of the National Security Organization by the citizens of East Germany and demolishment of some of the dossiers in archives can be counted. When the archives of this institution were held open to the public opinion in 1992, the debates blazed up because some of the dossiers were infiltrated the press and it was revealed that some important artists and writers spied on. Writer Hans Joachim Schädlich who migrated to the Federal Republic Germany in 1997 as a result of pressures in GDR learns for the first time that his brother carried information about him to this institution and experiences disappointment. In the short story called Die Sache mit B. he published after a few months, the writer confronts with this betrayal. Using the technique of backscattering, he narrates his brother's role in the family and the relations between brothers conspicuously starting from his childhood till the moment he wrote this story. In this story which includes a great number of references to autobiographical elements, while the narrator struggles with the will of reaching the reality, he also questions this betrayal by mentioning family memoirs in his memory. In the story, his brother Karlheinz Schädlich commits suicide in 2007 possibly because he understands that he can't live with this embarrassment anymore. In this study, firstly how the writer approached to the betrayal theme considering political, cultural, social and autobiographical sources will be examined and then the story of Die Sache mit B. will be examined with the framework of M. Halbwachs' family memory theory. Moreover, this study will contribute to the understanding and interpretation of literary works that reflects such family memoirs and carries autobiographical elements.

Key words: The German Democratic Republic, autobiography, Hans Joachim Schädlich, betrayal, family memory.

\section{Giriş}

Almanya tarihi bakımından en önemli dönüm noktalarından sayılan 1989 yılında Berlin Duvarı'nın yıkılması ve bir yıl sonrasında Demokratik Almanya Cumhuriyeti'nin (DAC) resmi olarak Federal Almanya'ya katılması kırk yıllık bir devletin sonunu da beraberinde getirmiştir. Her şeyden önce insanlar Almanya'nın artık iki ayrı devlet olmadığına ve sınırdan öteki tarafa kolayca geçebileceklerine inanamıyorlardı, çünkü siyasal ve düşüngüsel dizgeye uyum sağlamayan kişilere, özellikle sanatçı ve yazarlara çeştli baskılar uygulanmış, yasaklar getirilmiş ve cezalar verilmiştir. Bu nedenle birleşim yıllarında baskı ve zulmün bir simgesi sayılan Devlet Güvenlik Teşkilatı (Staatssicherheisdienst; kısaca StaSi) halk tarafından büyük bir öfkeyle yağmalanır. 1992 yılında ise arşivler kamuoyuna açılır. Arşivler açıldıktan sonra pek çok kişi kendisi hakkında yazılmış olan dosyaları incelemiş ve aynı zamanda bazı sanatçıların ve yazarların muhbirlik yaptığı konusunda kimi bilgiler basın yayına sızdırılmıştır. İnsanlar büyük bir şaşkınlık içerisindedir: DAC' nin kendi halkını denetim altında tutabilmek için korkunç ve devasa bir denetim mekanizmasını inşa ettiği ortaya çıkmıştır. Yazar Hans Joachim Schädlich ilk defa burada ağabeyinin casusluk yaptığını ve kendisiyle ilgili özel bilgileri bu kuruma servis ettiğini öğrendiğinde büyük bir travma geçirmiştir. Hemen sonrasında 1992 yılında yayımladığı Die Sache mit B. (Schädlich H. J., Die Sache mit B., 1992) adlı kısa öyküsünde geri sapım tekniği ile çocukluğundan bu yazıyı kaleme aldığı ana kadar ağabeyinin aile içindeki rolünü ve ağabey kardeş ilişkilerini aktararak ihanet izleğini sorgulamıştır. Dergilerde ve gazetelerde ele alınan bu metin, genel olarak ihanete uğrayan 
bir yazarın hem ağabeyine karşı hem de bu olaya karşı bir yanıtı olarak okunmuştur. Her ne kadar özyaşamsal ögeler bulunsa da, bu yapıtın özyaşamöyküsel ulamda ele alınması güç görünmektedir, çünkü Ali Tilbe’nin Fransız Özkurgu Romanı adlı çalışmasında “Özyaşamöyküsünde ‘yazar, anlatıcı ve anlatı kişisinnin kimliği tanınır nitelikte olmalıdır.” (Tilbe, 2017, s. 26) tespiti burada geçerli değildir.

Nadine Nowroth’un da belirttiği gibi 1989 yılında Berlin Duvarı yıkıldıktan sonra DAC'deki hayatı betimleyen “özyaşamöyküsel bellek yazını”3 büyük artış göstermiştir (Nowroth, 2012, s. 149), çünkü Doğu Almanya'da yaşayan insanlar için kelimelerle betimlenmesi neredeyse mümkün olmayan önemli bir tarihi süreçten geçilmişti ve yaşanan bu çalkantılı süreci aktarmanın etkili bir yolu bellek yazınında mümkün olabilirdi. 1989 yılından önce batıya göç etmiş olan veya DAC'de kalmayı tercih eden yazarların çoğu özyaşamöyküsel anlatımla uğradıkları haksızlıkları geçmişle hesaplaşma eğsinimiyle yansıtmaya çaba göstermiştir, çünkü bir taraftan anımsamak unutmaya karşı direnmektir anlayışıyla gerçeklerin gün yüzüne çıkmasına katkı sağlamayı erek edinmişler, ama diğer taraftan yazın yardımıyla yaşatılan acılarla yüzleşmenin kişisel olarak kendilerini rahatlatabileceği veya ancak bu şekilde sorunun üstesinden gelebilecekleri umudunu taşımışlardır.

$\mathrm{Bu}$ yapitta ihanet izleği ele alınırken ağabey-kardeş arasında geçen anıların süredizimsel olarak konumlandırılması ve sorgulanması Halbwachs'ın aile belleği bağlamında ortaya koyduğu düşünceleriyle koşutluk göstermektedir, bundan dolayı bu kuramın metin üzerinde uygulanması elverişli görünmektedir. Ancak bu konuya geçmeden önce Hans Joachim Schädlich’in 1992 yllından çok önce, yani Die Sache mit B. yayımlanmadan önce ihanet olgusu ve izleğine nasıl yaklaştığına, ardından Devlet Güvenlik Teşkilatı’nda ihaneti ortaya çıkarttığında ilk tepkisine, bir sonraki aşamada genel hatlarıyla özellikle batı yazınında ihanet izleğinin önemi ve nasıl ele alındığına, son olarak ise Schädlich’ın yapıtını ihanet izleği bağlamında diğerlerinden ayıran özelliğine değinilecektir.

\section{1. “Olur da, günün birinde hain olursam, hakkım neyse verilsin: ölüm”: Hans Joachim Schädlich ve ihanetten beslenen imgelem}

Hans Joachim Schädlich’in ilk kitabı olan Versuchte Nähe (Ulaşılmaya Çalışılan Yakınlık) ve daha sonraki yazınsal çalışmalarının çoğunda dikkat çeken önemli noktalardan biri, gerçeklik ile kurmaca arasındaki ilişkidir: "Gerçekler ile kurmaca arasında bir sınır çekmekte zorlanıyorum" (Schädlich H. J., Der Roman, 2005, s. 134) ifadesinde kurmaca ile gerçekliğin sınırlarının akışkan olduğunu, ikisi arasında ayırım yapmanın zorluğunu ve sınırlarının açık bir biçimde belirlenemeyeceğini anlatmaya çalışmaktadır. Pek çok yapıtında ele aldığ yazınsal çalışmalarında kullanarak kendi deyimiyle "gerçeğe dayalı tarihselliği imgelemek" (s. 134) çabasında olduğu söyenebilir. Nikodemus Frischlin (1974) öyküsünde veya Tallhover (1986) romanında olduğu gibi Almanya tarihinde tanınmış kişilerin özgeçmişlerinden ve yaşamöykülerinden yararlanılarak, aynı zamanda kendi özgeçmişinden veya güncel sorunlardan beslenerek üretmek yoluna gidilmiştir. Theo Buck'un da vurguladığı gibi “Belgeler ve gerçekler Hans Joachim Schädlich’in yazıları için önemli ölçüde esin kayağı olmuştur.” (Buck, Hans Joachim Schädlich. Leben zwischen Wirklichkeit und Fiktion, 2015, s. 9), aynı şekilde Peter von Matt'ta onu belgeleri, kaynakları ve tutanakları yazınsal üretiminde ustaca kullanabilen bir yazman olarak görmektedir (Matt, 2007). Bundan dolayı ilk kitabının yayımlanma süreci epey zorlu geçmiş olması olasıdır, çünkü bu kitap doğu Almanya'daki olumsuz ve sıradan yaşamı, bireyin yabancılaşmasını ve Kafkavari yazım biçimini benimsediği gerekçesiyle yayımlanmamş ve toplumcu düzene saldırı olarak değerlendirilmiştir (Schädlich H. J., Der andere Blick,

3 Bu makalede Maurice Halbwachs ve Ali Tilbe’nin kitaplarının dışındaki tüm alıntılar tarafımdan çevirilmiştir.

\footnotetext{
Adres | Adress1 
Literature and Betrayal: Examining Betrayal Theme in Hans Joachim Schädlich's Work Called Die Sache mit B. within The Context of Family Memory / Y. Aydın (p. 323-338)

1992)4. Belli ki DAC'deki ekin siyasetinde öngörülen toplumcu gerçekçilik ilkelerine sadık olmayan bir yapıt olarak görülmüştü. 1976 yılında ozan Wolf Biermann’ı yurttaşlıktan çıarılmasına karşı çıkan bildirgenin altına imzasını attığı için hedef noktası haline gelen ve Berlin Bilimler Akademisi üyeliğini kaybeden yazar, artık Doğu Almanya'da yazınsal anlamda üretken olamayacağını anladığından Federal Almanya'ya göç etmek için başvuruda bulunur. Bu süreçte ne kadar baskı altında yaşadığını, hatta eşine kocasından boşanması konusunda ne tür baskılar yapıldığını yazar Literatur und Politik. Fahndungsobjekt Schriftsteller (1995) yazısında belgelerle ortaya koymuştur, Versuchte Nähe'nin yayımlanma sürecinde yaşanan engeller ise Über Dreck, Politik und Literatur'de (1990) ayrıntılı bir biçimde betimlenmiştir. Ayrıca kızı Susanne Schädlich de Immer wieder Dezember. Der Westen, der Stasi, der Onkel und ich adlı kitabında yaşananları çarpıcı bir biçimde aktarmıştır. Yaşatılan varoluş yoksunluğu doğudan ayrılmanın temel nedeniydi kızına göre (Schädlich S. , 2014, s. 35). 1977 yllında yurttaşlıktan çıkarıldıktan sonra iki kızı ve eşiyle batıya yerleşen yazar yeni ortamına uyum sağlayabilmek için aşağı yukarı dört beş yıla ihtiyacı olduğunu belirtmiştir (Schädlich H. J., "Die sonderbare Bindung an den 'Stall', aus dem man kommt". Ein Gespräch mit Martin Ahrends vom Februar 1989, 1995, s. 13).

Yazarın 1992 yllından önceki yıllarda - ağabeyinin ihanetini deşifre etmeden önce - hem denemelerinde hem de yazınsal yapıtlarında ihanet ve sadakat izleklerini konu ettiği, yani ihanet sorunsalını bilimsel uzamda yazınbilimsel ve yazıntarihsel açıdan ele aldığı, sanatsal uzamda ise ihanetten beslenen imgelemi kurmaca yapıtlarında yansıttığı söylenebilir. Buck'un "insancıl güven ve ihanet arasındaki ayırım Schädlich'i DAC'de sürekli meşgul etmiştir.” (Buck, Hans Joachim Schädlich. Leben zwischen Wirklichkeit und Fiktion, 2015, s. 54) düşüncesi esasen eksik sayllabilir, çünkü güven ve ihanet ilişkisi sadece DAC'de yaşarken değil, aynı zamanda Federal Almanya'ya göç ettikten sonra da yazarı zihinsel olarak sürekli meşgul etmiştir. Sözgelimi 07.03. 1987 tarihinde Verraten und verkauft (İhanete uğramış ve satılmış) başlıklı bildirisinde 19. yüzyılda yaşamış olan yazar Georg Büchner'in5 arkadaşı olan Christian Gustav Clemm'in Büchner'e ihanet ettiğini belgelerle ortaya koyar. İhanet sözcügünün ne anlama geldiğini ve hainlerin niteliklerini kısaca belirttikten sonra Büchner’i zor duruma düşüren ve 1935 yılında cezaevine girmesine neden olan ihaneti, yazarın ailesine yazmış olduğu mektuplardan alıntı yapılarak açılarnır. Yazının değişik kısımlarında yinelenen ve sözlüklerden alıntı yapılan şu cümle Schädlich için ihanetin tanımı açısından önemlidir; ihanet "Güven ilişkisinin daha önce bağlı olunan bir olayın (kötü niyetli) terk edilmesi uğruna yıkılması” (Schädlich H. J., Verraten und verkauft, 1992, s. 39) anlamına gelmektedir. 1974 yllında Kurzer Bericht vom Todfall des Nikodemus Frischlin. Aus den Quellen (Nikodemus Frischlin’in ölümü hakkında kısa bir rapor. Kaynaklardan alınmıştır) adlı kısa öyküsünde ise yazıları nedeniyle 16. yüzyılda asilzadelerin düşmanlı̆̆ını kazanan Tübingen Üniversitesi profesörü Philipp Nicodemus Frischlin'in Hohenurach kalesindeki hapishaneden yatak çarşaflarını birbirine bağlayarak kaçmaya çalışması ve çarşafların yırtılması sonucunda kayalıklardan düşerek can vermesini konu etmiştir. Başlıkta belirtilen "Kaynaklardan alınmıştır" ifadesi yazarın belgelerden yola çıkarak tarihselliği imgeleme yoluna gittiğinin bir göstergesidir. Dönemin diline sadık kalınarak öykülenen Frischlin’in hapishaneye atılmasının nedeni, hücre koşulları, sorgulama biçimleri ve duruşmada hakimle tartışmaları kimi yerde Frischlin’in bakış açısıyla kimi yerde de egemen bakış açısıyla anlatılmaktadır. Kurmacanın ve belgeselliğin nerede başlayıp nerede bittiğini anlamak okur için her zaman kolay olmamakla beraber, bu iki öğe iç içe geçmiştir ve akışkandır. Schädlich, Frischlin’in kılığına bürünürek esasen kendine ait yaşanmış özyaşamsal öğeleri, özellikle içinde bulunduğu durumu

\footnotetext{
$4 \quad$ Hans Joachim Schädlich Der andere Blick makalesinde Versuchte Nähe yapıtının yayımlanma sürecinde ne tür baskılar ve engellerle karşılaştı ğını ayrıntılı bir biçimde betimlemiştir.

Georg Büchner (1813-1837) 1834 yılında İnsanlar Hakları Topluluğu’nun kurucularındandır. Schädlich yazısında bu topluluğa üye olabilmek için verilmesi gereken bir yemine gönderme yapar: "Olur da günün birinde hain olursam, hakkım neyse verilmeli: ölüm.” (Schädlich H. J., Verraten und verkauft, 1992, s. 37). Klemm’de bu topluluğun üyesiydi.
} 
tarihselliğe ve belgelere dayalı bir başka kişinin özyaşamıyla birleştirerek bir öykü üretmiştir. Öykünün son cümleleri olan ve Frischlin için söylenen sözler şunlardır: "Kendi memleketinde yabancı, kamusal tekzipe mahküm, yine de inatla, acının ekmeği ve üzüntünün suyu ile beslenmiş olarak soğuk bir gecede yola koyuldu" (Schädlich H. J., Kurzer Bericht vom Todfall des Nikodemus Frischlin. Aus den Quellen, 1977, s. 202). Bu sözlerin Schädlich’in kendi yaşadıklarından ve kendisine yaşatılanlardan dolayı içinde bulunduğu durumdan kaynaklanan hisleriyle örtüşebileceğini söylemek mümkündür. Görüldüğü gibi ihanet imgelemi bu öyküde 16. yüzyılda yaşamış bir aydının yazıları nedeniyle eleştiri oklarını üzerine çekmesi ve bundan dolayı vatan haini suçlaması nedeniyle cezalandırılması üzerinden gerçekleşmiştir. İhanet izleğinin konu edildiği en önemli yapıtlardan biri kuşkusuz 1986 yllında yayımlanan Tallhover romanıdır. Yine burada da 19. yüzyılda yaşamış olan Leonhard Tallhover adlı bir cellat ve onun bir dizi casusluk eylemleri konu edilmiş, yani belgelerden hareketle tarihselliği imgeleme yoluna gidilmiştir. Kurmaca yaşamöyküsü olarak değerlendirilen bu romanda 136. yaşına ulaşan Tallhover, Prusya döneminde iktidar için, Hitler döneminde Nasyonal Sosyalizm için ve Demokratik Almanya Cumhuriyeti’nde Almanya Toplumcu Birlik partisi için çalışmış, her türlü erk ve yetkeye hizmet vermiş bir casustur. Buck'un deyimiyle Tallhover "Kendini hizmete vermişliğinde insan olarak kaybeder." (Buck, Hans Joachim Schädlich. Leben zwischen Wirklichkeit und Fiktion, 2015, s. 113). Her devrin adamı, her türlü yetkenin ve erkin hizmetinde olan ve hizmet etmeyi de her türlü düşüngü sisteminden üstün gören Tallhover daha sonra görevini kötüye kullandı̆̆ı düşünülünce uzaklaştırılır. Suçunu kendine itiraf ettikten ve yalnızlaştıktan sonra infaz edilmesi için adeta yalvarır ve 13 Şubat 1955 yllında söylediği şu son sözleriyle roman sonlanır: "Ağzını kapar, ağzını açar, bir şeyler söyler, kendi sesini duymaz. Bağırır, ama sadece fisıldadığını duyar, Neden kimse gelmiyor! Neden kimse yardım etmiyor bana! Yoldaşlar! Gelin! Yardım edin bana! Öldürün beni!” (Schädlich H. J., Tallhover. Roman, 2004, s. 283). Bu romandan çok etkilenen yazar Günter Grass, Schädlich'in izniyle Tallhover karakterini Ein weites Feld romanında kullanmışsa da, canlandırdığı karakterle işlenen suçu küçük göstermeye çalıştığı yönündeki yorumlar nedeniyle, iki arkadaş arasındaki ilişki zamanla bozulmuştur (Schädlich H. J., Tallhover - ein weites Feld. Autobiographische Notiz, 2005).

Başına gelecek ihaneti öngörürcesine güven, sadakat, dürüstlük gibi niteliklere bu kadar değer veren ve bunları yapıtlarında hem bilimsel hem de yazınsal ulamda sorgulayan Hans Joachim Schädlich’in 1992 yılında ağabeyinin ihanetini ortaya çıkarttığında ne kadar yıkılmış olabileceği tahmin edilebilir.

\section{2.“İntihar son ihanet olurdu.”: İhanetin İtirafı}

Almanların toplumsal belleğinde yer eden son derece önemli siyasal, ekinsel ve toplumsal dönüşümlerin yaşandığı 1989 ve 1992 yıllarında, Almanların kaderini değiştirecek ve artık tek bir devlet ve bir toplum olma yolunda önemli adımlar atılacaktı. 9 Kasım 1989 yılında Berlin Duvarı'nın yıkılmasıyla Doğu ile Batı arasındaki sınır ortadan kalkar.

Her şey gerçekte DAC’nin seyahat yasasındaki değişikliği duyurmasıyla başlar. 9 Kasım 1989 yılında saat 19.0o dolaylarında basın açıklaması yapan basın sözcüsü Günter Schabowski yeni seyahat yasasında ve sınır geçişinde yapılan düzenlemeyi duyurarak batıya seyahat etmek isteyen kişiler konusunda bütün sınırlamaların kalktığını bildirir. Yeni düzenleme bir gün sonra yürürlüğe girecekti, ancak bir gazetecenin bu düzenlemenin ne zamandan itibaren geçerli olduğu konusundaki kıvrak ve ani sorusu üzerine Schabowski birden bire şaşırır ve yanlışlıkla hemen” yanıtını verir. Bunun üzerine binlerce kişi sınırlara yığılır, duvarın üzerine çıkarlar ve kimi yerde halk ile sınır güvenliğinden sorumlu polisler arasında büyük arbede yaşanır. Özellikle Brandenburg Kapısında polisle tartışmaya giren, ağlayarak sadece bir kez gidip hemen döneceğini söyleyen ve polislere izin vermeleri için adeta yalvaran bir kadın 
Literature and Betrayal: Examining Betrayal Theme in Hans Joachim Schädlich's Work Called Die Sache mit B. within The Context of Family Memory / Y. Aydın (p. 323-338)

Doğu Almanya'da katı sınır geçiş yasası nedeniyle özgürce batıya seyahat edemeyen hatta gizlice öteki tarafa gitmek isterken can veren bütün insanların bir simgesi haline gelmişti: Brandenburg Kapısı'ndaki kadın halkın iktidara artık yeter diyen bir haykırışıydı.

Hans Jachim Schädlich de duvar yıkıldıktan sonra Brandenburg Kapısı'na giderek sevincini köpüklü şampanya içerek kutlar (Schädlich S. , 2014, s. 225). Yazarın kızı Susanne Schädlich ise bu tarihi olaya bir türlü inanamaz, duvarsız bir Almanya’yı düşünmekte zorlanır (Schädlich S. , 2014, s. 226).

Tüm bu çalkantalı günlerde Hans Joachim Schädlich hep DAC-Diktatörlüğünün Nazi-Dikatörlüğünden pek farkı olmadığını, bir an önce geçmişle hesaplaşmaya gidilmesi, suçluların ve suça iştirak edenlerin suçlarını itiraf etmeleri gerektiğini belirtmiş ve unutmaya karşı direnmenin önemini 1990 yllında vurgulamıştır: "Almanya'daki en genç diktatörlüğün duvarı yıkıldı. Bir şeyler yapılmalı. İsrailli arkadaşımın, şair Asher Reich'in söylediklerini söylüyorum: '-Yeniden - inşa edilen unutma duvarının yıkılmak zorunda olduğunu söyle.” (Schädlich H. J., Die Stunde Null. Oder ist heute gestern?, 1992, s. 21)

Devlet Güvenlik Teşkilatı́nda bulunan dosyalar yok edilsin söylentilerine şiddetle karşıllı veren Schädlich, herkese geçmişte yaşanan ve yaşatılan baskıları ve haksızlıkları aydınlatma konusunda sorumluluk düştüğünü ve bu konuda herkesin katkıda bulunması gerektiğini şu benzetmeyle dile getirir:

İhanete uğrayan bir kişi, kendisi de sık sık ihanete uğrayan işbirlikçi haine karşı nasıl bir tutum sergilemeli? İhanete uğrayan haham Schlomo'nun önerdiği gibi mi bir tutum sergilemeli? "Şayet bir insan pislik ve çamurun içinden çıkarmak istiyorsan, sakın yukarıda durabileceğini ve ona yardım elini uzatmakla yetinebileceğini düşünme. İnmelisin tamamen aşağıya, çamurun ve pisliğin içine. İşte orada güçlü ellerle kavra onu ve onu ve kendini ışığa taşı. “(Schädlich H. J., Die Stunde Null. Oder ist heute gestern?, 1992, s. 17-18)

Yazara göre "kendi suçunu kabul etmek kefaretin ilk adımıdır" (Schädlich H. J., Die Stunde Null. Oder ist heute gestern?, 1992, s. 20), o nedenle suçlu olan kişiler sorumluluklarından kaçmamalıdır ve hatalarıyla yüzleşmelidir. Ancak bu durumda bizlere düşen görev ise onu dinlemek ve anlamaya çalışmaktır.

Duvar yıkıldıktan yaklaşık üç ay sonra 15 Ocak 1990'da Devlet Güvenlik Teşkilatı binası halk tarafından yağmalanır. Binanın kapıları ve camları kırılır, arşivlerde bulunan dosyaların bir kısmı tahrip edilir, bir kısmı ise halk tarafından büyük bir öfkeyle pencerelerden aşağıya atılır. Halkın bu kuruma karşı beslediği öfke ve kin, basın yayında ele alınıyor ve her yerde yansitılıyordu. Gizli dinlemelerle halkı denetim altında tutmaya çalışan ve halkı binlerce casusuyla gözetleyen Devlet Güvenlik Teşkilatı (DGT) ürkünç teşkilat yapısıyla halkın gözünde baskının ve zulmün simgesiydi.

Ancak 2 Ocak 1992 yılında bu kurumda bulunan arşivler Gauck-Makamı adı altında yeniden düzenlenir ve hakkında dosya düzenlenmiş olan kişiler bu makama başvurarak dosyalara bakabilme hakkına sahip olur. Ne var ki bazı yazarların ve sanatçıların kimi dosyaları gizli bir şekilde basın yayına sızdırılınca yeniden büyük bir tartışma başlar. 1990 yllında Reiner Kunze ve 1993 yllında ise Christa Wolf gibi yazarlar, haklarında düzenlenmiş dosyaları yayımlayarak geçmişle yüzleşme ve hesaplaşma adına önemli katkılar sağlamak istemişlerdir. Hans Joachim Schädlich ilk defa 21 Ocak 1992 yllında GauckMakamı’nda hakkında "Schädling” (zararlı) kod adıyla dosyalar tutulduğunu öğrenir. 22 Ocak’ta ise oraya giderek ağabeyi Karlheinz Schädlich’in kod adı "Schäfer" (çoban) olarak DGT'de muhbirlik yaptığını öğrenir. İlkin orada bulunan bir arkadaşına ağabeyinin ihanetini ortaya çkarttığını söyleyen Schädlich'e arkadaşı önce evine gitmesi ve kendini toparlaması gerektiğini söyler. Evine gitmek için 
arabasına bindiğinde ağlama krizi geçirir ve büyük öfkeyle arabanın ön camlarını yumruklar. 23 Ocakta ağabeyi ile önce telefonda konuşur, sonra ise buluşur ve ağabeyi ihaneti sonunda itiraf eder. "Hissettiğim utancı artık taşıyamıyorum" ve "şimdi son verebilirim" (Schädlich S. , 2014, s. 230) diyerek intihar edebileceğini söylemesi üzerine Hans Joachim Schädlich "intihar son ihanet olurdu” (s. 230) diye yanit verir ve olayların aydınlatılması için katkıda bulunması, casusluk yaparak zarar verdiği kişilerden özür dilemesi gerektiğini söyler. Öyle ki Hans Joachim Schädlich 1974 - 1977 yılları arasında on dört kez bir araya gelen Doğu-Batı-Almanya yazarlarının buluşmalarına ağabeyi Karlheinz Schädlich’i de davet etmiş, o ise bu toplantıya katılan yazarlar hakkında gizlice DGT'ye bilgi vererek onlara zarar vermişti. Günter Grass, Sarah Kirsch, Thomas Brasch, Kurt Bartsch, Uwe Johnson, Bernd Jentzsch, Aras Ören, Reiner Kunze, Nicolas Born, Elke Erb, Adolf Endler, Dieter Schubert, Klaus Schlesinger, Klaus Poche, Max Frisch ve Jurek Becker gibi yazarların da katıldığı, yazarların fikir alışverişinde bulunduğu ve yayımlanmamış metinlerinden kesitler okunduğu bu toplantılar için Schädlich "benim okulumdu" (Schädlich H. J., Das beste ist natürlich, man hat gar nichts mit Diktaturen zu tun. Gespräch mit Wolfgang Müller, 2005, s. 270) demiştir, yine başka bir yerde bu buluşmaların kendisi için "ilk doğubatı buluşmaları" ve "eşsiz" (Schädlich H. J., Deutsche im deutschen Exil?, 1992, s. 93) olduğunu vurgulamıştır.

"Ailenin içinden geçen depremdi” (Schädlich S. , 2014, s. 227) diye ifade eder Susanne Schädlich amcasının ihaneti ailede duyulduğunda. Kendisinin amcasıyla arasında yakın bir bağı vardı: "Amcam sadece bir parça aile demek değildi benim için, aynı zamanda iyi bir dosttu, tam anlamıyla benim en iyi arkadaşımdı.” (s. 179) sözlerinden ne kadar düş kırıklığı yaşadığı tahmin edilebilir. Üzüntü, öfke ve düş kırıklığı gibi duygular bütün aile üyelerini derinden sarsmıştı.

Oysa Hans Joachim Schädlich her defasında daha önce belirttiklerini yineliyor ve "yeniden inşa edilen unutma duvarını yıkmak zorundayı" (Schädlich H. J., Vorwort, 1992, s. 9) diyerek, muhtemelen ağabeyinin geçmişle ilgili bir açıklama yapmasını bekliyordu. Bunun yanısıra casusların kimliğini öğrenme istenci içindeydi ve bunu sorguluyordu:

\begin{abstract}
Başkaların yeterince yamltabilen, onları bir diktatörlüğün baskı mekanizmasına teslim edebilen birinin nasıl bir insan olduğunu bilmek istiyorum. Böyle bir muhbirle şu sorulara yanıt vermesi için konuşmak istiyorum: Bunu neden yaptın? İhanet sisteminin içsel bağından kendini kurtarmak için ne yapmak istiyorsun? Bundan sonra nasl bir tutum sergileyeceksin? Benden ne bekliyorsun? (Schädlich H. J., Jeder ist klug, der eine vorher, der andere nachher, 1992, s. 169)
\end{abstract}

Sistemin casuslardan beklentilerini arşivlerde bulunan dosyalarda inceler ve en büyük hedeflerden birinin gözetledikleri kişinin meslektaşlarını, arkadaşlarını ve akrabalarını casus olarak kullanmak olduğunu üzülerek öğrenir (s. 168).

Ancak ağabeyden ne yazık ki beklenen geçmişi aydınlatma eğilimi gelmez, aksine o suskunluğunu korumayı seçer ve 2007 yllında aile tekrar büyük bir sarsıntı geçirir: Karlheinz Schädlich, bir parkta bulunan bankın üzerinde başına doğrulttuğu bir tabancayla intihar eder.

Görünen o ki, ağabeyinin ihaneti ailenin içinde öyle derin bir yara bırakmıştır ki, kolay kolay bunun üstesinden gelinemez. Susanne Schädlich’in sözlerinden de anlaşlacağı gibi "İhanet tedavi edilemez. İhanet bir yaradır ve öyle kalacaktır. İhanet yıllanmaz. Bir bağışlanma yoktur.” (Schädlich S. , 2014, s. 238). Karlheinz Schädlich ne yazık ki geçmişin aydınlatılmasında, geçmişle hesaplaşmada bir katkıda bulunmamıştır, susarak yanıtlanması gereken soruları yanıtsız bırakmıştır ve kardeşinin "intihar son ihanet olurdu" sözünü dikkate almadan geçmişteki ihanetiyle başkalarına vermiş olduğu zararın cezasının infazını kendi eliyle gerçekleştirmiştir. 
Literature and Betrayal: Examining Betrayal Theme in Hans Joachim Schädlich's Work Called Die Sache mit B. within The Context of Family Memory / Y. Aydın (p. 323-338)

\section{Yazın ve İhanet}

Hans Joachim Schädlich 22 Ocak 1992 yllında ağabeyinin ihanetini ortaya çıkarttıktan birkaç ay sonra Die Sache mit B. (B. olayı ile ilgili) adlı kısa öyküsünü yayımlar ve ağabeyinin ihanetini ve itirafını ele alır. İhanet konusunda bu kadar duyarlı olan ve daha önce de gerek bilimsel, gerek sanatsal açıdan ihaneti sorgulayan, bunu yapitlarında önemli bir malzeme haline getiren yazar, bu sefer bizzat kendi yaşadığı ve acıyla deneyimlediği en yakını tarafından ihanete uğramıştır.

İhanet eden veya hain olarak bilinen karakterler veya kişiler yazında, dini inançlarda veya söylencelerde yansımasını bulmuştur: Kabil'in değil de Habil'in adağı Tanrı tarafından kabul edildiği için, Kabil'in kardeşini öldürmesi, yine Hz. Yusuf'un kardeşleri tarafından kuyuya atılması, Hz. İsa'yı ele veren havarisi Yahuda, Zeus'e hayvanların en değersiz kısımlarını sunak olarak vermeye çalışan Prometheus, Gustave Flaubert'in Madame Bovary'si veya Shakespeare'da İago karakterleri ihanetin temsilleri olarak kabul edilirler ve kuşkusuz bu örnekler çoğaltılabilir. Genel olarak ihanet, her şeyden önce bir kimsenin güvenini suistimal etmek, onu yanıltmak, bilinçli olarak yanlış yönlere saptırmak, bir kimseye kendini sadakatle bağlıymış gibi göstermek yoluyla ortaya konulan bir tutumdur, yani bağlllığın bir simgesi olan güven ve aldatma arasındaki ilişkinin kırılma noktasını teşkil eder.

Yazınsal metinlerde bir izlek olarak ihanet sık sık karşımıza çıkan önemli bir izlektir. Horst S. ve Ingrid G. Daemmrich'in "Themen und Motive in der Literatur" (Dünya Yazınında İzlekler ve Örgeler) (Daemmrich \& Daemmrich, 1995, s. 340-341) başlıklı el kitabında ihanet, yanıltma ile bir arada ele alınmıştır; devingen olduğu ve zıtlıkları ortaya koyduğu için olay örgüsüne heyecan ve gerilim kattığı belirtilir. Yanıltma bağlamında kötü davranışlar olarak yanlış bilgi aktarmak, sahtekârlık, yanlış yola sevk etmek, kendini farklı bir biçimde tanıtmak, sadakatsizlik ve ihanet gibi davranışların yansıtıldığı vurgulanır. Genel olarak özetlemek gererekirse şu noktalarda yanıltma başka deyişle ihanet izleğinin ele alındığı ortaya konur: 1. uzun süredir tanınmayan ve kan bağı olan birinin cinayetinin gizlenmesinde, 2. kadın erkek ilişkilerinde çiftlerden birinin diğerini aldatmasında, 3. genellikle mizahi bir dille yansıtılan erkek kardeşlerin, hükümdarların, hizmetkârların, kralların ve dilencilerin rol değişimlerinde, 4. bir adaletsizliği veya bir toplumun ahlaki çöküntüsünü ortaya çıkarmak için bir sahtekârın dolandırıcılığında. Die Sache mit B. göz önünde bulundurulduğunda dördüncü noktaya yakın öğeler taşıdığını söylebiliriz, yani ağabeyin ihanetiyle genelde bir sistemin çöküntüsü özelde ise bu durumun bir aileye etkisi ortaya konmuştur. Bu öykünün diğer öykülerden farkı yoğun bir biçimde özyaşamdan besleniyor olmasıdır.

Doğudan batıya göç ettikten bir yıl sonra 1978 yılında Nicolas Born ile yaptığı bir röportajda (Born, 1992) bilinçli olarak kendini biraz geri çektiğini, çünkü insanların kendisinin yapıtlarıyla ilgilenmek yerine kimliği ve kişiliği ile ilgilenmelerinden rahatsızlık duyduğunu belirten yazar, bu sefer yayımladığı kısa öyküsüyle neredeyse tamamen kimliği üzerinden kamuoyunun odak noktası haline gelmiştir. Bu öykünün ilk denemesi çöpe atılmıştır, çünkü yazara göre çok yoğun duygular içerisinde yazılmıştı. Schädlich bu süreci şu şekilde ifade etmektedir: "Daha sonra ancak şu şekilde bunun yapılabileceğini fark ettim, dahil olan birisi olarak bile veya en azından betimleyen birisi olarak kendi duyumlarınızı, kendi duygularınızı katı bir biçimde uzak tutarsanız, kendiniz de kurtuluyorsunuz." (Schädlich H. J., Das beste ist natürlich, man hat gar nichts mit Diktaturen zu tun. Gespräch mit Wolfgang Müller, 2005, s. 292). Her ne kadar kamuoyu bu metni ağabeyinin ihanetine uğrayan birinin ona bir yanıtı olarak okusa ve öykü içinde de özyaşamöyküsel öğelere göndergeler bulunsa bile, sözcük oyunları veya eğretileme sanatı kullanılarak bir ölçüde yaşanmış gerçeklikle kurmaca bir potada eritilmiştir. "Metnim şiddetli bir biçimde gerçek gerçekliğe yapışmakta. Başka türlü olsaydı, iyiydi.” (Schädlich H. J., Die 
Sache mit B., 1992, s. 88) gibi bir tümceyle yaşanmış gerçekliği yansıtmanın rahatsızlığı veya "Metnim şiddetli bir biçimde gerçek gerçekdışılığa yapışmakta. Başka türlü olsaydı iyiydi” (s. 89) tümcesiyle ise yaşanmamış kurmaca gerçekliğini yansıtmanın rahatsızlığı yansıtılmaktadır gerçekte.

Theo Buck yazara ilişkin "Kitaplarının hiç de az sayılmayacak bir kısmı anı ve bellekten beslendi” (Buck, Hans Joachim Schädlich. Leben zwischen Wirklichkeit und Fiktion, 2015, s. 9) derken burada önemli bir noktaya değinmektedir, çünkü anı ve bellek Schädlich’in yazınsal çalışmalarında vazgeçilmez bir üretim alanı ve yansıma alanı yaratmıştır. Die Sache mit B. öyküsünde aile ilişkilerine ve ağabey kardeş arasındaki bağa geniş yer verildiği için aile belleği kuramı çerçevesinde analiz edilmesi uygun olacaktır. ${ }^{6}$

\section{Maurice Halbwachs ve Aile Belleğinin Toplumsal Çerçevesi}

Bellek araştırmalarına bakıldığında belleği içsel bir sorundan, ruhbilimi veya nöroloji alanından çıkarıp toplumsal ve ekinsel bir alana taşıyan ilk Maurice Halbwachs olmuştur. 16 Mart 1945’te Buchenwald toplama kampına götürülen ve orada ölen Fransız toplumbilimci Halbwachs düşünceleriyle 20. yüzyılın ikinci yarısında patlak veren bellek araştırmalarına temel oluşturmuş, yeni araştırmalara da yön vermiştir. Çalışmalarının kaynağında belleğin toplumsal temellere dayandığı kanıtlanmaya çalışılmıştır. Bireysel bir bellekten söz etsek bile toplumsal çerçeve eksikliği söz konusuysa onun da varlığını sürdüremeyeceği ileri sürülmüştür. Burada toplumsal çerçeveyle bireyin herhangi bir gruba veya gruplara olan aidiyeti, sözgelimi aile veya dini gruplara olan aidiyeti kastedilmektedir.

Uzun yıllar bellek araştırmaları yapan Jan Assman her ne kadar Maurice Halbwachs'ın eşsiz çalışmalarının önemini vurgulasa da, tarihselliğin red edilmesini, ekin kuramı açısından yeni bir bakış açısının geliştirilmemiş olmasını ve ruhbiliminin göz ardı edilmesini, kısaca odak noktası olarak sadece toplum bilimine ağırlık verilmesini eleştirmiştir (Assman, 1992). Eski yazılar üzerine araştırmalar yapan ve belleği genelde ekinsel ile iletişimsel bellek olarak ikiye ayıran Assman ayrıca Halbwachs'ın kuramının temellerini tamamen yaşam ve gerçeklik üzerine dayandırmış olmasını da bir eksiklik olarak yorumlamıştır.

Ancak yaşam ve gerçeklik arasındaki bağ ve bunun aktarımı yaşamöyküsel veya özyaşamöyküsel anlatıların vazgeçilmez ögeleridir, bu nedenle Halbwachs'ın kuramı ve özellikle ailenin toplumsal belleği bağlamında ileri sürülen düşünceler, aile anılarının yer verildiği özyaşamsal öğelerin bulunduğu metinlerin çözümlenmesi için elverişli görünmektedir. Bu konuya geçmeden önce aile belleği için de son derece önemli olan anıların konumlandırılması ve sorgulanmasıyla ne anlaşıldığına kısaca değinmekte yarar var. Burada öncelikle bir anıyı tanımakla bir anıı konumlandırmak arasındaki ayırıma dikkat çekilir: bir anı eğer konumlandırılabiliyorsa, onun hakkında bir fikrimiz vardır, söz gelimi zaman ve uzam hakkında bilgi verebiliriz, oysa tanımakta uzam ve mekan hakkında kesin bilgi veremesek bile dışarıda gördüğümüz herhangi bir şeyi daha önce gördüğümüz hissi yeterlidir. O halde konumlandırmak daha çok bir fikir ile iligiliyken, tanımak daha çok bir hisle ilgilidir. Halbwachs bu iki olgunun kısmen geçişken olduğunu belirtir: "Bu fikir bu hisse eklendiğinde anı hem tanınmış hem de konumlandırılmış olur. Nitekim tanınmayan ama konumlandırılan bir anı yoktur ama sadece tanınan lakin konumlandırılamayan pek çok anı vardır." (Halbwachs, 2016, s. 153). Anıların konumlandırılması ise belleğin sorgulanması açısından önemlidir, çünkü anılarımızı ne kadar iyi konumlandırabilirsek, o kadar çok bellekte sorgulandığı vurgulanır (s. 153-154). Belleğin sorgulanması durumu ise "Muhakeme ile kastettiğimiz, başkalarının düşündüğünü anlamamıza ve onlarla ortak olarak düşünmemize olanak tanıyan zihinsel faaliyet türü” (s. 154) olarak açlklanır, ancak Halbwachs'e göre ruhbilimcilerin

6 Aile derken burada anne, baba ve çocuklardan oluşan çekirdek aileden yola çıkılmaktadır. 
Literature and Betrayal: Examining Betrayal Theme in Hans Joachim Schädlich’s Work Called Die Sache mit B. within The Context of Family Memory / Y. Aydın (p. 323-338)

benimsemiş olduğu bu tanım yeterli değildir, çünkü burada zaman, uzam ve gruba vurgu yapılır: "Bizi etkilemiş bir olayın ortaya çıktığı an ve yeri, grubumuzda tanımlandıkları şekilleriyle mekanda ve zamanda aramaya pekala mecburuz" (s. 154). Birey belleğinde sorguladığı bir olayı grubundan, zamandan veya uzamdan ayrı yapamaz, belleğin toplumsal çerçevesiyle anlatılmak istenen esasen budur. Toplumsal çerçeveyi oluşturan gruplardan biri saylan aileye de bir bellek atfedilir. Bu bellek ailenin her üyesinin bilincinde varlığını sürdürür. Üyelerin uzak yerlerde bulunması bile ortak aile geçmişinin anımsanmasına engel teşkil etmemektedir: "Aile hatıraları [...] aile grubun çeşitli üyelerinin bilinci içinde gelişir. Yakın olmalarına rağmen hayatın aralarına bir mesafe koyduğu durumlarda bile her biri, ortak aile geçmişini kendine özgü tarzda hatırlar." (Halbwachs, 2016, s. 190). O halde aile belleğinde belirleyici olan şey, ortak aile geçmişlerinin olmasıdır. Bu ortak aile geçmişleri aynı zamanda ailenin kendine özgü gelenek ve göreneklerini belirler, böylece ailenin "kendine özgü ruh[u]" (s. 214) da çıkmış olur.

Bununla birlikte ailevi yaşamımızda belleğimize kazınmış olan bir olayı betimlerken, o olayın o günün atmosferinde aynı şekilde karşımıza çımayacă̆ı, onun yeniden inşa edildiği belirtilir:

\begin{abstract}
Akrabalarımızın karakterlerinin bulunduğu, evimizde geçen bir sahne, o zaman yașadiğımız şekliyle bir günün tablosu olarak yeniden ortaya çıkmaz. Onu yeniden inşa ederiz. Ondan önce ve sonra gelen pek çok dönemden ödünç alınmış unsurları içine sokarız. Akrabalarımızın ahlaki tabiatına ve bizzat belli bir mesafeden değerlendirilebilecek o olaya dair o an sahip olduğumuz kavram, esinlenmekten kaçamayacağımı biçimde zihnimizde epey güçlü bir şekilde dayatılır. Aile yaşamamızdan doğan aile yaşamımızı özetleyen ve de daha az önemli özellikleri, koşulları konumlandırmak isteyenlere işaret noktası görevi gören bu olaylar ve figürler için de aynısı geçerli. (Halbwachs, 2016, s. 197)
\end{abstract}

Son olarak aile belleği bağlamında ele alınan ve son derece önemli görünen nokta ise aile üyelerinin her birinin diğerleri hakkında oluşturduğu "zengin ve açık" olarak nitelenen imgedir:

Grubun her bireyinin daha ziyade «kendi türü içinde eşsiz» olarak görüldüğü ve başka birinin yerine geçebileceğini ne tasarlayabildiğimiz ne de tasarladığımız başka bir yer yoktur. (...) dışa göreli olarak kapah bir ortamda, yani ailemizde, birbirimizle girdiğimiz gündelik ilişsiler vasitasiyla birbirimizi uzun uzun ve her bakımdan inceleriz. Bu şekilde, her bir aile üyesinin hafizasında, diğer herkese dair özellikle zengin ve açık bir imge oluşur. (Halbwachs, 2016, s. 209)

Özetlemek gerekirse; aile anılarının toplumsal çerçevesini belirlemek için uzam, zaman ve kişilerin dikkate alınması gerekmektedir, aile anıları araya mesafeler girse bile her üyenin belleğinde gelişmektedir ki bu da o aileye özgü ruhu ortaya koymaktadır, aile belleğinde yer etmiş bir olay betimlenirken o olay esasen yeniden inşa edilmektedir ve her aile üyesinin belleğinde diğeri hakkında açık bir imge oluşturulmuştur.

\title{
5.“B. ve ben, henüz bizdik.“: Die Sache mit B. adlı öykünün M. Halbwachs'ın Aile Belleği Kuramı Bağlamında Analizi
}

"B” harfi Almanca'da Bruder (ağabey/ birader) veya Beobachter (gözlemci) sözcüklerinin baş harfi olduğundan ağabeyinin bir yandan casusluk eylemlerine diğer yandan aile ilişkilerine gönderme olarak kullanılmış olabilir. Tekil birinci kişi adılı kullanılarak betimlenen olaylarda kahramanın çocukluğundan itibaren yaşadığı ana kadar genelde süredizimsel olarak ağabeyi ile deneyimlediği anlar gözler önüne serilmektedir. Kullanılan dil tutanak biçeminde kısa, açık, yalındır ve kahramanların iç dünyalarına yer verilmemektedir. Bu öyküyü Halbwachs'ın genelde belleğin toplumsal çerçeveleri ve özelde aile belleği bağlamında incelenebilmesi için öncelikle aile anılarında geçen olayaların nasıl konumlandırıldığına, yani zaman, uzam ve kişilerin nasıl aktarıldığına göz atmak gerekiyor. 
Tablo 1'den de anlaşılacağı gibi ağabeyi anlatıcıya dört yaşından yedi yaşına kadar kardan adam yapmasını, uçurtma uçurmasını, hesap yapmasını ve yüzmeyi öğretmiş, okul ödevlerinde yardımcı olmuştur. Çocukluk dönemlerinde uzamın aktarılması dikkate alındığında evinin önü, çayırda, havuzda ve evde gibi uzamlardan bahsedilmektedir. Burada dikkat çeken nokta mutfakta yemek yerken ifadesi için "her mevsimde“ ifadesinin yer almasıdır. Ergenlik dönemi ile ilgili iki anıya yer verilmiştir: bir kızla dans etmesi ve lise mezuniyet balosunda ağabeyinin rolü. Üniversite yıllarına dair bir olaya gönderme yapılmıştır: başka bir şehirde ağabeyi ve iki arakadaşıyla evi paylaşması. Zaman konusunda bilgi verilmemekle birlikte anlatıcı tek başına izin yaparken aniden ağabeyinin karşısına çıktığı belirtilmiştir. Çocukluk dönemiyle birlikte en çok yazar olarak çalışırken ağabeyi ile beraber geçirilen anılar betimlenmiştir. Yine ansızın bir şehirde karşısına çıktığı, evde Doğu ve Batı Almanya yazarları buluşmasına katıldığı ve yine evde ağabeyinin Doğu Almanya'da partiden atılacağı konuşulduğu, ayrıca sınır ötesinde -ki burada Batı Almanya kastedilmektedir muhtemelen- beş altı kez buluştukları aktarılmaktadır. Son anı ise ağabeyinin ihaneti itiraf ettiği zamandır ve burada uzam ve zaman bilgisi yoktur. Bu anının betimlenirken konumlandırılmamasının sebebi yakın tarihte olması, anlatıcının büyük şok geçirmiş olması ve bundan dolayı tam olarak sorgulanamaması olarak açıklanabilir. Ancak okur olarak elbette bu olayın 1992 yılında gerçekleştiğini bilmekteyiz. Yansıtılan anıların her birinin, yani ağabeyi ve kardeşinin bilincinde var olduğundan yola çıkmak durumundayız.

Öyküden de anlaşlacağı gibi belirli aralıklarla ağabey ve kardeş bir araya gelmektedirler, kimi zaman ayrı uzamlarda veya ayrı kentlerde yaşasalar bile yine bir araya geldikleri ve buluştukları aktarılmaktadır:

Oturmayı öğrendiğimden beri, her mevsimde B. ile aym yemek masasında oturdum, bir keresinde yazın yemekten sonra "Bugün yüzmeye gidelim" dendiğinde de. B. ve ben "bizdik". Ben 5-6 yaşlarındaydım. Henüz hiç yüzmeye gitmemiştim. Sadece suya girmiştim. Nasıl yüzmeye gidildiğini anlatmama gerek yok. Gidilir sonra da yüzülür. B. havuza atladı ve yüzdü. Havuzun kenarında duruyordum ve nasl yüzüldüğünü bilmiyordum. B. "Suya gir!" dedi. Fakat ben girmedim. İşte o zaman B. havuzdan çıtı ve beni itti. Anımsadığım kadarılala, bağırdım: "Adi köpek!" Havanın geri kalan kısmına nefes almak için ihitiyacım vardı. B. "Yüz!" dedi. Tepindim, su yuttum, B. havuzda nasıl hareket ediyorsa ben de aşağı yukarı öyle hareket ettim ve boğulmadım. Şimdi aşağı yukarı nasıl yüzüldüğünü öğrendim. (Schädlich H. J., Die Sache mit B., 1992, s. 82)

Anlatıcı çocukluğunda yüzmeyi ağabeyinden acı bir biçimde öğrenmiştir ve onunla "her mevsimde" aynı yemek masasında oturduğunu belirtmesi ailenin içerisinde belirli bir geleneğin olduğunu da göstermektedir. Ailenin içerisinde gelişen bu olayların anımsanması Halbwachs'ın ileri sürdüğü gibi aile üyelerinin uzak yerlerde bulunması ortak aile geçmişlerinin anımsanmasına bir engel oluşturmadığı ve belirli arahıkla ailenin içerisinde yinelenen gelenek ve görenekler ailenin "kendine özgü ruh[unu]" yansıttığı (Halbwachs, 2016, s. 190) düşünceleriyle koşutluk göstermektedir.

Aile üyeleri arasında anne ve babanın dışında diğer kardeşlere7 bu öyküde hiç yer verilmemiştir. Babanın kaybının ise ağabeyini ne kadar etkilediği anımsanmaktadır: "Olayların tarihsel sıralamasına hep uymadığım için, şimdi artık rahatlıkla anlatabilirim, B.'nin ve benim baba olarak adlandırdığımız kişi artık var olmadığında, B. bir keresinde, esasen kendi hayatının sona erdiğini söyledi.”

\footnotetext{
$7 \quad$ Hans Joachim Schädlich 1935 yılında Saksonya eyaletinde bulunan Reichenbach'ta doğmuștur. Kendisinden dört yaş büyük (Karlheinz) ve iki yaş büyük (Dieter) ağabeyleri ve bir de iki yaş küçük kız kardeşiyle büyüyen Schädlich henüz sekiz yaşındayken babasını kaybeder.
} 
Literature and Betrayal: Examining Betrayal Theme in Hans Joachim Schädlich's Work Called Die Sache mit B. within The Context of Family Memory / Y. Aydın (p. 323-338)

(Schädlich H. J., Die Sache mit B., 1992, s. 84). Okulun mezuniyet balosuna babaları öldüğü için, onun yerine ağabeyinin geldiğinin belirtilmesi, kardeş ilişkilerinin ötesinde anlatıcının ağabeyi ile arasında kimi zaman baba oğul ilişkisi olduğunu ve onu babanın yerine koyduğunu göstermektedir.

Diğer önemli bir nokta ise, aile içinde ağabeye büyük ve anlatıcıya küçük takma adının verilmesidir (s 83). Takma adının verilmesi aile üyelerinin zihninde o kişilerle ilgili bir imgenin oluşturulduğunun bir göstergesidir: büyük ağabeyi olgun ve eğitici, küçük kardeş ise daha çok yardıma muhtaç ve toydur. Bu durum da yine Halbwachs'ın ortaya koyduğu aile üyelerinin diğerleri hakkında oluşturduğu ve başka birinin diğerinin yerine geçemeyeceği zengin ve açık bir imgenin oluşturulması saviyla büyük benzerlik göstermektedir (Halbwachs, 2016, s. 209).

Duygulara pek yer verilmeyen öyküde anlatıcının çocukluğından itibaren ağabeyi ile olan ilişkisi ve ona olan yakın bağı yansıtılmış ve öykü ağabeyin, ihaneti -her ne kadar ihanet sözcüğü kullanılmasa da- itiraf etmesi ile son bulmuştur. Ağabey ile yaşanan anılarda zaman ve uzam konusunda bilgi verildiğini görmekteyiz. Aile içindeki anıların bellekte sorgulanıp sorgulanmadığını ve Halbwachs'ın anlayışına göre "başkalarının düşündüğünü anlamamıza ve onlarla ortak olarak düşünmemize olanak tanıyan zihinsel faaliyet” (Halbwachs, 2016, s. 154) içerisinde bulunup bulunulmadığı şu sözlerden daha iyi anlaşılmaktadır:

B. ile ilgili olayı tümüyle anlatamam. Yani, sürekli yanımızda bulunan gözetleyen biri olsaydı, o zaman o gözetleyen kişi, eğer yaşıyorsa ve eğer istiyorsa ve bunu yapabilirse, $B$. ile ilgili olayı tümüyle anlatabilir. Sonuç itibariyle B. diye bir vard. B. yaşıyor. Kendisini hiç gözetleyip gözetlemediğini bilmiyorum; ona sormadım. Ona sorsaydım ve o "evet" deseydi, yani: "Evet, ben kendimi gözetledim“ deseydi, o zaman kendisini gerçekten gözetleyip gözetlemediğini bilmezdim. Bilseydim, o zaman B. ile ilgili olayı, yani kendisiyle ilgili olan olayı anlatmak isteyip istemediğini bilmezdim. Ve bunu yapabilir miydi bilmezdim. Belki istiyordur, ama yapamıyordur. Belki yapabiliyordur, ama istemiyordur. (Schädlich H. J., Die Sache mit B., 1992, s. 81)

Görüldüğü gibi anlatıcı konumunda olan yazar kelime oyunları yaparak ağabeyinin ihanetini sorgulmaktadır ve ağabeyinin neler düşündüğünü ve bundan sonra neler yapmak istediğini merak etmektedir. Yine metnin sonlarına bakıldığında ihanetin itiraf edildiği an canlandırılmaktadır: "B. kötü oldu, 'Evet, bu gerçek. Şimdi ne yapayım. Sen hakkında konuştuğum tek kişi değildin. Önemli biri bile değildin.' dedi. Dedim ki: 'Buna inanırım. Bunu gördüm. Diğerlerine git ve onlara de ki: 'Evet, bu gerçek.'” (Schädlich H. J., Die Sache mit B., 1992, s. 89).

Anlatıcı çaresiz olan ağabeyine nasıl bir tutum sergilemesi gerektiğini açıklar. Zaman ve uzam konusunda metinde bilgi verilmemiştir, ancak kaynaklardan Karlheinz Schädlich'in ilk defa 23 Ocak 1992'de telefonda ihaneti itiraf ettiği, daha sonra ise kardeşiyle bu konuyu yüz yüze konuştuğu bilinmektedir.

Kuşkusuz bu öyküde aile anıları betimlenirken, çocukluk, gençlik, ergenlik ve yazarlık dönemlerine ait ağabeyi ilgili anılar anlatılırken geçmişte yaşanan o günün, o anın atmosferi içinde ve aynı hislerle aktarıldığını ileri sürmek pek doğru olmaz, bunun zorluğunu anlatıcı kimi yerlerde metin içinde ima etmiştir. O nedenle Halbwachs'ın deyimiyle burada aile anıları yeniden inşa edilmiştir diyebiliriz (Halbwachs, 2016, s. 197). Ancak ortaya çıkan tabloda bir imgenin düzeltimine gidildiği, ağabey imgesinin değiştiği ve ailenin güven ve birliktelik ruhunun yara aldığı söylenebilir. Birkaç kez yinelenen tümce "B. ve ben 'bizdik" (Schädlich H. J., Die Sache mit B., 1992, s. 81) anlatıcının geçmişte ağabeyi ile yakın, dost ve bir bütün olduğuna oysa yazının yazıldığı an bu birlikteliğin artık bozulduğuna işaret etmektedir. 


\section{Sonuç}

Bir yazar olarak özgürce çalışamayacağını anlayan ve 1977 yılında Doğu Almanya'dan Batı Almanya'ya göç eden Hans Joachim Schädlich ihanet izleğini yapıtlarında hem bilimsel hem de yazınsal ulamda yansıtmıştır. Yazınsal çalışmalarında genelde geçmişte yaşamış yazar veya şairlerin yaşamöykülerinden yararlanarak üretme yoluna giden ve tarihte hain olarak bilinen veya ihanete uğrayan kişilerin yaşamöykülerinden beslenen Schädlich, belgelerden yola çıarak tarihselliği imgeleme çabasıyla önemli yapıtlar ortaya koymuştur. 1992 yılında Almanya'nın birleşiminden sonra ağabeyi Karlheinz Schädlich'in DAC'de casus olarak çalıştı̆̆ını, hem kendisi hem de yakınları hakkında bilgiler servis ettiğini öğrendikten sonra ihanet konusunda bu kadar duyarlı olan ve bu nedenle ihaneti yapitlarında sorgulayan yazar, bu sefer ihaneti çok acı bir biçimde deneyimlemiştir. Die Sache mit B. adlı kısa öyküsü bu ihaneti sorgulayan bir yapittır.

Maurice Halbwachs'ın aile belleği kuramının bu yapıtta uygulanmasının olası olduğu görülmüştür, çünkü burada bellek toplumsal temellere dayandırılmaktadır. Bu anlayışına göre her ne kadar bireysel bir bellekten söz etsek bile kişinin yaşadığı toplumsal çerçeve dikkate alınmadan bellekten de söz edemeyiz. Anıların ise bellekte sorgulanabilmesi için konumlandırılmaları gerekmektedir ve bunun için kişinin içinde bulunduğu grubu -ki bu grup aile de olabilir- ve bu grubun üyelerinin içinde bulunduğu zamanı ve uzamı dikkate almak zorunda olduğumuz belirtilmiştir. Burada önemli olan nokta, özyaşamöyküsel anlatıların da vazgeçilmez ögeleri olan gerçeklik ve yaşamdan yola çıkılmasıdır. Bundan ötürü Die Sache mit B. yapıtının bu kurama göre çözümlenmesi elverişli görünmektedir. Aile belleği kuramında üç özellik dikkat çekmektedir: 1. ailenin kendine özgü ruhu vardır. 2. aile anıları betimlendiğinde, esasen anılar yeniden inşa edilmektedir ve 3. her aile üyesinin belleğinde diğeri hakkında bir imge oluşturulmuştur.

Buna göre Die Sache mit $B$. öyküsünde anlatıcının ağabeyi ile birlikte yaşadığı bütün zaman ve uzamlar tespit edilmiştir. Aileye de bir bellek atfedildiği ve bunun aile üyeleri içinde gerçekleştiği, üyeler uzakta olsa bile ailenin kendine özgü ruhu korunduğu, aile anılarının açı bir biçimde konumlandırıldığı ve sogulandığı, anılar betimlenirken yeniden inşa edildiği ve anlatıcının ağabeyi hakkında bir imge oluşturduğu tespit edilmiştir. Bu incelemenin sonucunda ağabeyin ihaneti nedeniyle, ailenin kendine özgü ruhuna gölge düştüğü ve özellikle ağabey hakkında oluşturulmuş imgenin değiştiği söylenebilir: güven, sadakat ve birliktelik açısından imgenin düzeltimine gidildiği görülmektedir.

Maurice Halbwachs'ın aile belleği kuramı bağlamında ortaya koyduğu düşünceler, özellikle aile anılarının yansıtıldığı veya aile anılarında yaşanmış acı veya sevinçli olayların aktarıldı ̆̆ı yaşamöyküsel veya özyaşamöyküsel anlatıların daha iyi anlaşılması için önemli bir katkı sağlamaktadır.

\section{Kaynakça}

Arnold, H. L. (Dü.). (1995). Hans Joachim Schädlich (Cilt I/95, Heft 125). München: edition text + kritik.

Assman, J. (1992). Schrift, Erinnerung und politische Identität in frühen Hochkulturen. München: Beck.

Born, N. (1992). Ich bin mit den Un-Mächtigen. Gepräch mit Nicolas Born. H. J. Schädlich içinde, Über Dreck, Politik und Literatur. Aufsätze Reden, Gespräche, Kurzprosa (s. 118-125). Berlin: Literarisches Colloquium.

Buck, T. (1995). Von der "versuchten Nähe" zur "versuchten Ferne": Schädlichs narrativer Weg "zur Freiheit in der Geschichte". (H. L. Arnold, Dü.) Text + Kritik, 1/95, s. 17-29. 
Literature and Betrayal: Examining Betrayal Theme in Hans Joachim Schädlich’s Work Called Die Sache mit B. within The Context of Family Memory / Y. Aydın (p. 323-338)

Buck, T. (2015). Hans Joachim Schädlich. Leben zwischen Wirklichkeit und Fiktion. Köln, Weimar, Wien: böhlau.

Daemmrich, H. S., \& Daemmrich, I. G. (1995). Themen und Motive in der Literatur. Ein Handbuch. Tübingen, Basel: Francke.

Halbwachs, M. (2016). Hafizanın Toplumsal Çerçevesi. (B. Uçar, Çev.) Ankara: Heretik.

Joachim Walther, W. B.-J. (Hrsg.). (1991). Protokoll eines Tribunals. Die Ausschlüsse aus dem DDRSchriftstellerverband 1979. Hamburg: rororo.

Matt, P. v. (2007, März 31). Die Phantasie des Protokollanten. Frankfurter Allgemeine Zeitung(31.03.2007/ Nr. 77).

Nowroth, N. (2012). Von Sachen, Spitzeln, und Schafspelzen. Eine interkulturelle Analyse der Werke "Die Sache mit B." von Hans Joachim Schädlich und "Immer wieder Dezember" von Susanne Schädlich. Focus on German Studies(Vol. 19), s. 149-167.

Roth, J.-R. (2010). Die Literatur und der Untergang der DDR. Beispiele aus vierzig Jahren. SanktAugustin, Berlin: Konrad-Adenauer-Stiftung.

Schädlich, H. J. (1977). Kurzer Bericht vom Todfall des Nikodemus Frischlin. Aus den Quellen. H. J. Schädlich içinde, Versuchte Nähe (s. 196-202). Hamburg: Rowohlt.

Schädlich, H. J. (Dü.). (1992). Aktenkundig. Mit Beiträgen von Wolf Biermann, Jürgen Fuchs, Jochim Gauck, Lutz Rathenow, Vera Wollenberger u.a. Berlin: Rowohlt.

Schädlich, H. J. (1992). Der andere Blick. In H. J. Schädlich, Über Dreck, Politik und Literatur (S. 103112). Berlin: Literarisches Colloquium.

Schädlich, H. J. (1992). Deutsche im deutschen Exil? H. J. Schädlich içinde, Über Dreck, Politik und Literatur. Aufsätze, Reden, Gespräche, Kurzprosa (s. 85-98). Berlin: Literarisches Colloquium.

Schädlich, H. J. (1992, September). Die Sache mit B. (K. Michel, \& T. Spengler, Dü) Kursbuch: Deutschland, Deutschland, s. 81-89.

Schädlich, H. J. (1992). Die Stunde Null. Oder ist heute gestern? H. J. Schädlich içinde, Über Dreck, Politik und Literatur. Aufsätze, Reden, Gespräche, Kurzprosa (s. 9-21). Berlin: Literarisches Colloqium.

Schädlich, H. J. (1992). Ich bin mit den Un-Mächtigen. Gepräch mit Nicolas Born. H. J. Schädlich içinde, Über Dreck, Politik und Literatur. Aufsätze Reden, Gespräche, Kurzprosa (s. 118-125). Berlin: Literarisches Colloquium.

Schädlich, H. J. (1992). Jeder ist klug, der eine vorher, der andere nachher. H. J. Schädlich (Dü.) içinde, Aktenkundig. Mit Beiträgen von Wolf Biermann, Jürgen Fuchs, Joachim Gauck, Lutz Rathenauw, Vera Wollenberger u.a. (s. 166-172). Berlin: Rowohlt.

Schädlich, H. J. (1992). Über Dreck, Politik und Literatur. Aufsätze, Reden, Gespräche, Kurzprosa. Berlin: Literarisches Colloquium.

Schädlich, H. J. (1992). Verraten und verkauft. H. J. Schädlich içinde, Über Dreck, Politik und Literatur (s. 34-40). Berlin: Literarisches Colloquium.

Schädlich, H. J. (1992). Vorwort. H. J. Schädlich (Dü.) içinde, Aktenkundig. Mit Beiträgen von Wolf Biermann, Jürgen Fuchs, Joachim Gauck, Lutz Rathenow, Vera Wollenberger u.a. (s. 7-10). Berlin: Rowohlt.

Schädlich, H. J. (1995). "Die sonderbare Bindung an den 'Stall', aus dem man kommt". Ein Gespräch mit Martin Ahrends vom Februar 1989. H. L. Arnold (Dü.) içinde, Hans Joachim Schädlich (Cilt I/ 95, Heft 125, s. 9-16). München: text + kritik.

Schädlich, H. J. (2004). Tallhover. Roman. Hamburg: Rowohlt.

Schädlich, H. J. (2005). Das beste ist natürlich, man hat gar nichts mit Diktaturen zu tun. Gespräch mit Wolfgang Müller. H. J. Schädlich içinde, Der andere Blick. Aufsätze, Reden, Gespräche (s. 258298). Hamburg: Rowohlt. 
Schädlich, H. J. (2005). Der Roman. H. K. Schädlich içinde, Der Andere Blick. Aufsätze, Reden, Gespräche (s. 132-139). Hamburg: Rowohlt.

Schädlich, H. J. (2005). Literatur und Politik. Fahndungsobjekt Schriftsteller. H. J. Schädlich içinde, Der andere Blick (s. 57-86). Hamburg: Rowohlt.

Schädlich, H. J. (2005). Tallhover - ein weites Feld. Autobiographische Notiz. H. J. Schädlich içinde, Der andere Blick. Aufsätze, Reden, Gespräche (s. 140-152). Reinbeck bei Hamburg: Rowohlt.

Schädlich, S. (2014). Immer wieder Dezember. Der Westen, die Stasi, der Onkel und ich. München: Knaur.

Tilbe, A. (2017). Çağdaş Fransız Özkurgu Romanı. Tekirdă̆: Toprak Ofset Matbaacılık. 
Literature and Betrayal: Examining Betrayal Theme in Hans Joachim Schädlich's Work Called Die Sache mit B. within The Context of Family Memory / Y. Aydın (p. 323-338)

\begin{tabular}{|c|c|c|c|}
\hline Zaman & Uzam & Kiși/ Kişiler & Olay \\
\hline 4-5 yaşlarında/ kış & evinin önü/ dışarısı & ağabeyi ile birlikte & kardan adam \\
\hline 3-4 yaşlarında/ sonbahar & çayırda/ dışarda & ağabeyi ile birlikte & uçurtma \\
\hline 5-6 yaşlarında/ yaz & havuz & ağabeyi ile birlikte & yüzme \\
\hline her mevsimde & mutfak & ağabeyi ile birlikte & yemek \\
\hline 6-7 yaşlarında/ ilkbahar & evde & ağabeyi ile birlikte & $\begin{array}{l}\text { okul ödevleri / hesap } \\
\text { yapma }\end{array}$ \\
\hline ergenlik dönemi & bir lokalde/ dışarda & $\begin{array}{l}\text { ağabeyi ve bir kı ile } \\
\text { birlikte }\end{array}$ & bir kızla dans etme \\
\hline ergenlik dönemi & evde/ dışarda & ağabeyi ile birlikte & lise mezuniyet balosu \\
\hline üniversite yılları & başka bir şehirde/ evde & $\begin{array}{l}\text { ağabeyi ve iki arkadaşı ile } \\
\text { birlikte }\end{array}$ & evi paylaşma \\
\hline izin yaparken & bir gölün kenarında & yalnız & $\begin{array}{l}\text { tesadüfen ağabeyi ile } \\
\text { karşılaşır }\end{array}$ \\
\hline yazar olarak çalışırken & büyük bir kentte/ otelde & yalnız & $\begin{array}{l}\text { tesadüfen ağabeyi } \\
\text { karşılaşır }\end{array}$ \\
\hline yazar olarak çalışırken & evde & pek çok yazar ile birlikte & $\begin{array}{l}\text { Doğu ve Batı Almanya } \\
\text { yazarları buluşmaları }\end{array}$ \\
\hline yazar olarak çalışırken & evde & ağabeyi ile birlikte & $\begin{array}{l}\text { ağabeyinin partiden } \\
\text { atılmasının konuşulması }\end{array}$ \\
\hline yazar olarak çalışırken & sınırın ötesinde bir yer & ağabeyi ile birlikte & 5-6 kez buluşma \\
\hline - & - & ağabeyi ile birlikte & itiraf (ihanet) \\
\hline
\end{tabular}

